FIU Law Review

Spring 2013

\title{
After Dothard: Female Correctional Workers and the Challenge to Employment Law
}

Brenda V. Smith

American University Washington College of Law

Melissa C. Loomis

Follow this and additional works at: https://ecollections.law.fiu.edu/lawreview

Part of the Other Law Commons

Online ISSN: 2643-7759

\section{Recommended Citation}

Brenda V. Smith \& Melissa C. Loomis, After Dothard: Female Correctional Workers and the Challenge to Employment Law, 8 FIU L. Rev. 469 (2013).

DOI: https://dx.doi.org/10.25148/lawrev.8.2.14

This Article is brought to you for free and open access by eCollections. It has been accepted for inclusion in FIU Law Review by an authorized editor of eCollections. For more information, please contact lisdavis@fiu.edu. 


\title{
After Dothard: Female Correctional Workers and the Challenge to Employment Law
}

\author{
Brenda V.Smith* \& Melissa C. Loomis**
}

This article examines a profession where women have made great strides-corrections. Using an equality framework, corrections and other non-traditional professions were the first target of the feminist movement in the 1970s. By and large, feminists were successful in creating greater porosity for women in law enforcement, emergency services, corrections, and the military. While women have entered these traditionally masculine spaces, they still suffer from an achievement gap. They are still underrepresented in leadership positions and marginalized in these settings; ${ }^{1}$ are still the targets of discrimination based on race, gender, and perceived sexual orientation; ${ }^{2}$ and are less likely than men to hold these positions and be married. ${ }^{3}$

Women's entry into correctional spaces has had several unintended consequences. First, it has complicated the experiences of other marginalized groups in those institutions. In particular, women's progress in correctional institutions has increased female inmates' exposure to supervision by male staff, which places them at greater risk for sexual victimization. Second, it has diminished privacy of both male and female inmates in custodial settings. Third, it has resulted in female correctional employees' disproportionate involvement in prohibited intimate contact with male inmates and youth in custody. The-

* Brenda V. Smith is Professor of Law at American University Washington College of Law and Director of the Project on Addressing Prison Rape.

** Melissa Loomis is a Research Fellow for the Project on Addressing Prison Rape. We would like to thank Takiya Wheeler, Rebecca Heinsen, and Amy Gordon for their research efforts.

1 See Membership in ASCA, Ass'N OF STATE CORR. AdMN'Rs, http://www.asca.net/projects/22/pages/173 (last visited Apr. 1, 2013).

2 Jill Harrison \& Kelsey A. Kanoff, Perceptions of Sexual Harassment on the Inside, 35 CORRECTIONS COMPENDIUM 8, 8 (2010) ("Perceptions of current recruitment practices differ by gender; and sexual harassment disproportionately affects female officers, which in turn negatively impacts their perceptions of staying in the field of corrections throughout the course of their career.").

3 Dana M. Britton, At Work in the Iron Cage: The Prison as Gendered ORGANIZATION 90 (2003) (noting that women entering corrections are more likely to be single). 
se sexual interactions have resulted variously in termination, resignation, prosecution, procreation, and litigation; complicating feminist theories of power, consent, and equality. Finally, it has complicated key employment law jurisprudence.

This article examines three areas of law and how female correctional staff's roles have complicated those doctrines: (1) privacy for inmates under the Fourth and Eighth Amendments; (2) the bona fide occupational qualification ("BFOQ") doctrine; and (3) sexual harassment under Title VII.

\section{FEMALE CORRECTIONAL WORKERS AS A SITE FOR INQUIRY}

An initial question is, why look at female correctional workers? I start from a very personal point of view. I have been lawyering in and around the edges of corrections for the past thirty years; first as a public defender, then as a lawyer providing legal services to women in custody, and finally as a legal professional challenging the system through litigation and policy change. ${ }^{4}$ During that time, I have had a tremendous amount of personal experience with women as correctional workers. They were the women who supervised my clientsmale and female, adult and juvenile-when I was a public defender. They were the strongest defenders and sometimes the worst enemies of women prisoners to whom I provided legal services. They were also strong allies in my litigation against a state department of corrections who I sued for a pattern and practice of discrimination against women in custody that included unequal programs and services, and a pattern and practice of abuse of women in custody. While I was suing on behalf of women inmates, female employees were complaining of similar treatment by the same correctional agency. ${ }^{6}$ Like female inmates, they complained of being sexually harassed and abused and having access to fewer opportunities than their male co-workers.

At the same time, working in prisons, jails, and juvenile facilities gave me access to other information about these women that bears a

\footnotetext{
4 My employment history includes positions at the District of Columbia Public Defender Service and the National Women's Law Center. In November 2003, I was appointed to the National Prison Rape Elimination Commission by the United States House of Representatives Minority Leader, Nancy Pelosi (D-Calif.) and served in that capacity until August 2009. In addition, I have run a project to train correctional leaders in hopes of preventing abuse against people in custody since 1999 .

5 Women Prisoners of the D.C. Dep't of Corr. v. Dist. of Columbia, 93 F.3d 910, 929 (D.C. Cir. 1996).

6 Neal v. Dir., D.C. Dep’t of Corr., No. 93-2420, 1995 WL 517244, at *1 (D.D.C. Aug. 9, 1995) (memorandum opinion) (complaining that the District of Columbia Department of Corrections permitted employees and inmates to sexually harass female correctional workers).

7 Id.
} 
startling congruency to the research. They were often single women with children. They were working in corrections because of the flexible hours, decent benefits, and job security.' And they faced a culture of disrespect from their male co-workers and often from their female colleagues. ${ }^{10}$ Many female staff members who worked with women I represented were resentful and disrespectful of female inmates; openly complaining that they would prefer to work with male inmates. They described male inmates as easier to supervise. Indeed, often $^{2}$ female staff whom I met while working with female inmates would seek my legal assistance for male inmates at other facilities. I later came to understand that these requests were for male inmates with whom the female staff shared intimate relationships - sometimes as sibling or relative, other times as lover.

Over the past three decades, women have become important players in the correctional milieu. Like all women, they tend to be better educated, ${ }^{13}$ more law abiding, and less likely to abuse alcohol or drugs than men. ${ }^{14}$ Consequently, they can pass background and drug tests, which have become de rigueur for most jobs. These requirements preclude many men, especially men of color, from employment. ${ }^{15}$ Additionally, because of gender expectations, correctional of-

8 See BRITTON, supra note 3, at 90.

$9 \quad$ Id.

10 Harrison \& Kanoff, supra note 2, at 8 (describing the difficulty female corrections officers face in relating to work colleagues, and the stress this places on female employees).

11 Early female correctional workers, commonly referred to as matrons, worked with female inmates in order to provide good examples. NICOLE HAHN RAFTER, PARTIAL JUSTICE: WOMEN IN STATE PRISONS, 1800-1935 14 (1985) (By the 1860s, the prescription for female staff noted that "[i]t is especially important ... that female officers should be distinguished for modesty of demeanor, and the exercise of domestic virtues, and that they should possess that intimate knowledge of household employment, which will enable them to teach the ignorant and neglected female prisoner how to economize her means, so as to guard her from the temptations caused by waste and extravagance."). Modern female correctional officers do not share the same sentiment with regard to the female inmates they oversee. Laura E. Bedard, Female vs. Male Inmates: The Rewards and Challenges of Managing Both, CORRECTIONS OnE (Sept. 16, 2008), http://www.correctionsone.com/corrections/articles/1843155-Female-vs-male-inmates-Therewards-and-challenges-of-managing-both/ ("When you tell a male inmate to tuck his shirt in, he does it. But when you tell a female inmate to tuck her shirt in, first she asks why, then she tells you about a million other inmates who didn't have to tuck their shirts in.'”).

12 See Bedard, supra note 11.

13 Achievement Gap, EDUC. WEEK (July 7, 2011), http://www.edweek.org/ew/issues/achievement-gap (observing that women consistently surpass men in terms of education).

14 Susan Nolen-Hoeksema, Gender Differences in Risk Factors and Consequences for Alcohol Use and Problems, 24 CliniCAL PsYCHOL. ReV. 981, 983 (2004) ("Women consistently drink less than men and have more alcohol-related problems than men.").

15 See, e.g., City of N.Y. DeP'T of Citywide Admin. Servs., Notice of EXAmination, CORRECTION OFFICER, available at http://www.nyc.gov/html/dcas/downloads/ pdf/noes/201303301000.pdf (noting the requirements for correctional officer employment in New 
ficers perceive women as being more professional and less predatory than male correctional staff. ${ }^{16}$ Finally, relying explicitly on those assumptions about gender performance, Title VII has gifted female correctional workers with the ability to supervise both male and female inmates in almost any situation, except that of viewing prolonged nudity and contact with genitalia of male inmates.

Rarely, however, do individuals totally conform to expectations, gender or otherwise. Experience has shown that female correctional workers still need the protection of Title VII to protect them from discrimination in opportunities, harassment, and abuse in the correctional workplace. Female correctional workers are doubly vulnerable in correctional settings. Male inmates can be predatory and undermining towards female officers. ${ }^{17}$ At the same time, male co-workers also engage in sexual harassment and assault of their fellow officers, and do not provide needed support in the workplace. ${ }^{1 .}$

Yet, female correctional workers in this powerful space are not behaving in ways we anticipate and are confounding neat theories of power, equality, and vulnerability. Over the past decade, largely because of the enactment of the Prison Rape Elimination Act ("PREA"), ${ }^{19}$ empirical information about predatory behavior in correctional environments has become clearer. In particular, data collected by the Bureau of Justice Statistics ("BJS") have shown that female staff are the most likely perpetrators of staff sexual abuse in custody. ${ }^{20}$ Their victims are overwhelmingly male.

York City, including educational requirements and the ability to pass a drug screening). But see EEOC ENFORCEMENT GUIDANCE NO. 915.002, CONSIDERATION OF ARREST AND CONVICTION RECORDS IN EMPLOYMENT DECISIONS UNDER TITLE VII OF THE CIVIL RIGHTS ACT OF 1964, available at http://www.eeoc.gov/laws/guidance/upload/arrest_conviction.pdf. ("An employer's neutral policy (e.g., excluding applicants from employment based on certain criminal conduct) may disproportionately impact some individuals protected under Title VII, and may violate the law if not job related and consistent with business necessity (disparate impact liability))."

16 Kay Levine, No Penis, No Problem, 33 Fordham Urb. L.J. 357, 358 (2006) (theorizing that although women also have the capacity to be predatory, the law is traditionally unwilling to view such women as abusers).

17 Brenda V. Smith, Uncomfortable Places, Close Spaces: Female Correctional Workers' Sexual Interactions with Men and Boys in Custody, 59 U.C.L.A. L. REV. 1690, 1698-99 (2012).

18 See infra Section II.

1942 U.S.C. $\$ 15601$ (2003).

20 Allen J. Beck, Paige Harrison \& Paul Guerino, Bureau of Just. Stat., NCJ 228416, SeXual Victimization In JuVEnile FACILITIEs Reported BY Youth, 2008-09 1 (2010), available at http://www.bjs.gov/content/pub/pdf/svjfry09.pdf (finding that female officers accounted for $95 \%$ of sexual abuse of juveniles in custody); ALLEN J. BECK \& CANDACE Johnson, Bureau of Just. Stat., NCJ 237363, SeXual Victimization Reported By FORMER STATE PRISONERS, 200815 (2012), available at http://www.bjs.gov/content/ $\mathrm{pub} / \mathrm{pdf} / \mathrm{svrfsp} 08$.pdf (finding that female officers accounted for $80 \%$ of all staff sexual misconduct). 
In the last Census of Correctional Authorities, women accounted for approximately $33 \%$ of the entire adult correctional workforce, an estimated 148,203 employees at the end of 2005. Among correctional workers in direct contact with inmates, men outnumbered women by a ratio of three to one. ${ }^{23}$ A 2007 report from the American Correctional Association suggests that women's participation in the correctional workforce increased to $37 \%$, with an estimated 144,274 , employees. ${ }^{24}$ Nonetheless, according to the latest BJS Report, correctional authorities report that female staff commits $61 \%$ of staff sexual misconduct and $21 \%$ of staff harassment. ${ }^{25}$ Sixty-nine percent of jail and prison inmates reporting victimization by staff sexual misconduct reported that female staff were the perpetrators. ${ }^{26}$ These figures are consistent with a recent survey of former state prisoners, which found that female staff accounted for roughly $80 \%$ of all incidents of staff sexual misconduct. ${ }^{27} \quad$ Likewise, surveys of juvenile correctional authorities and youth in custody reflect that female correctional workers have been involved in sexual abuse of youth in custody disproportionate to their numbers in the juvenile and corrections workforce. ${ }^{28}$ Women account for $42 \%$ of staff in juvenile facilities, yet youth implicate female staff in $95 \%$ of incidents of staff sexual abuse, where $92 \%$ of those abused youth are boys. ${ }^{29}$

So, even though female correctional workers may be vulnerable themselves, both to male inmates and male staff, their role confers power, which they can in turn abuse. In a series of recent cases in-

21 BECK \& JOHNSON, supra note 20, at 15 (viewing all staff sexual misconduct, female officers represent $78.7 \%$ of sexual misconduct with male inmates, but $1.3 \%$ of sexual misconduct with female inmates).

22 James J. Stephan, Bureau of Just. Stat., NCJ 222182, Census of State and Fed. CORR. FACILITIES, 20054 (2008), available at http://bjs.ojp.usdoj.gov/content/pub/pdf/csfcf05.pdf.

23 Id.

24 American Correctional Association, Adult Correctional Personnel by GENDER AND RACE (2007).

25 Paul Guerino \& Allen J. Beck, Bureau of Just. Stat., NCJ 231172, Sexual VictimizATION REPORTED BY AdULt CORRECTIONAL AUTHORITIES, 2007-2008 8 (2011), available at http://www.bjs.gov/content/pub/pdf/svraca0708.pdf.

26 Allen J. BECK ET AL., BurEAU OF Just. STAT., NCJ 231169, SEXUAL ViCTIMIZATION IN PRISONS AND JAILS REPORTED BY INMATES, 2008-09 24 (2010), available at http://bjs.ojp.usdoj.gov/content/pub/pdf/svpjri0809.pdf.

27 BECK \& JOHNSON, supra note 20, at 15.

28 GUERINO \& BECK, supra note 25, at 13.

29 BECK, HARRISON \& GUERINO, supra note 20, at 13. Although few reported cases involving female staff and female inmates exist, recent data suggests such abuse occurs in custodial settings. BECK \& JOHNSON, supra note 20 , at 15 (finding that $1.8 \%$ of all staff sexual misconduct involved conduct between female staff members and female inmates). This article's focus on men and boys in custody is not to suggest that the relationships with and abuse of women in custody is not as damaging to inmates, or less serious from an institutional, policy, or legal perspective. 
volving female staff abuse of male inmates, courts have recognized that even though male inmates may have willingly engaged in sexual contact with female staff, they, like female inmates, ${ }^{30}$ cannot consent to sex with an agent of the state. ${ }^{31}$ In Wood v. Beauclair, ${ }^{32}$ a male inmate ended a relationship with a female staff member after he discovered that she was married. ${ }^{33}$ The Ninth Circuit found that a female correctional officer violated a male inmate's Eighth Amendment rights when she conducted intrusive searches and threatened to discipline him. $^{34}$ In a separate case, Manago $v$. Williams, ${ }^{35}$ a female staff member performed oral sex on a mentally-ill male inmate. The United States District Court for the Eastern District of California found that the agency and its staff who allowed the abuse to happen in order to "catch the female staff member in the act" were potentially liable for damages to the inmate. ${ }^{36}$ Both cases demonstrate a necessary recalibration of courts' views of women and their potential for abuse of male inmates.

Even where sexual interactions between female staff and male inmates are not forcible or coerced, these relationships can have serious security implications for other staff, and for the facility and agency as a whole. In April 2013, federal authorities unsealed an indictment that revealed rampant corruption within the Baltimore City Detention Center, and identified thirteen female correctional officers who were involved in a conspiracy led by a prison gang to smuggle contra-

30 See, e.g., Chao v. Ballista, 806 F. Supp. 2d 358, 362-63 (D. Mass. 2011). In this case, a female inmate had between 50-100 sexual encounters with a male correctional officer. Id. The jury found that these encounters constituted an Eighth Amendment violation although the encounters were non-forced and non-coercive. $I d$. The jury found the individual officer and the prison superintendent jointly liable for $\$ 67,500$ and the individual officer for punitive damages of $\$ 6,200$. Id.

31 See, e.g., Buckles v. State, No. A08-2098, 2009 WL 2498635, at*1 (Minn. Ct. App. Aug. 18, 2009). A female correctional officer in the Minnesota Department of Corrections was caught bringing contraband to inmates and having sexual relations with five male inmates. Id. The officer pled guilty to five counts of third-degree criminal sexual conduct, and was sentenced to forty-six months. $I d$.

32692 F.3d 1041 (9th Cir. 2012).

33 Id. at 1044.

34 Id. at 1051.

35 No. 2:07-cv-2290, 2013 WL 1005118, at *3, 9 (E.D. Cal. Mar. 13, 2013).

36 Id.

37 Walker v. Taylorville Corr. Ctr., 129 F.3d 410, 413 (7th Cir. 1997); Watson v. Jones, 980 F.2d 1165, 1166 (8th Cir. 1992). Professor Brenda Smith and Professor Kay Levine of Emory Law School have begun a joint research project designed to discover the motives and potential interventions for female correctional workers who abuse men and boys in custody. This project is expected to continue through 2013. 
band into the detention center. ${ }^{38}$ The prison gang members sustained their enterprise by cultivating long-term sexual relationships with female correctional officers, which "cemented [their] business ties." According to the indictment, female correctional officers routinely had sexual relations with gang members inside the detention center. ${ }^{40}$ The lead defendant allegedly fathered five children with four correctional officers, while two officers tattooed his name on their bodies. The majority of the correctional officers involved in the scandal were young females.

Though there are few reported cases involving female staff who abuse female inmates, ${ }^{43}$ Daskalea v. District of Columbia, is instructive. In this case, female correctional staff forced Sunday Daskalea, a multiracial female inmate, to perform a strip tease for more than sixty inmates and male and female correctional employees. ${ }^{45}$ Surprisingly, the staff who arranged the event were female. ${ }^{46}$ In addition to forcing Ms. Daskalea to dance, the staff participated themselves. ${ }^{47}$ This incident is rife with contradiction. At the same time these female correctional officers were participating in the exploitation of a female inmate, female staff as a class had filed suit alleging a pattern and practice of sexual harassment from male correctional staff. ${ }^{48}$ It seems that these women sought to claim power by adopting behavior of those more powerful than they (male staff and perhaps in their view, male inmates), by oppressing someone who was more vulnerable, a multiracial female inmate in a predominantly African-American correctional system. ${ }^{49}$ Ironically, the Director of the Department of Correc-

38 Ann E. Marimow \& John Wagner, 13 Corrections Officers Indicted in Md., Accused of Aiding Gang's Drug Scheme, WAsH. Post (Apr. 23, 2013), http://articles. washingtonpost.com/2013-04-23/local/38756337_1_black-guerilla-family-bgf-state-prison.

39 Ian Duncan \& Jessica Anderson, Federal Authorities Indict Alleged Gang Members, Jail Guards, BALT. Sun (Apr. 24, 2013), http://articles.baltimoresun.com/2013-04-24/news/bs-md-cibgf-jail-indictment-20130423_1_jail-guards-city-jail-corrections-officers.

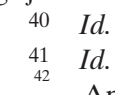

Annys Shin, Hiring Guards as Young as 18 May Have Fueled Baltimore Jail Scandal,
WASH. Post (Jun. 18, 2013), http://articles.washingtonpost.com/2013-0618/local/40046474_1_corrections-officers-black-guerilla-family-baltimore-jail-scandal.

43 BECK \& JOHNSON, supra note 20, at 15 (finding female inmates reporting unwilling sexual misconduct by female staff represented $4.6 \%$ of all reports of staff misconduct).

44227 F.3d 433 (D.C. Cir. 2000).

45 Id. at $437,439$.

46 Id. at 439.

47 Id.

48 Neal v. Dir., D.C. Dep’t of Corr., No. 93-2420, 1995 WL 517244, at *1 (D.D.C. Aug. 9 , 1995).

49 The DC Department of Corrections is over 93\% African American. See JAMES AUSTIN, ET. AL, CURRENT TRENDS IN THE DisTRICT OF COLUMBIA's JAIL POPULATION 7 tbl. 9 (The JFA Institute 2006), available at http://cjcc.dc.gov/sites/default/files/dc/sites/cjcc/publication/atta 
tions at that time was an African-American woman, who had replaced an African-American man who had himself been forced to resign because of allegations of his involvement in sexual harassment of female employees.

\section{WOMEN'S ENTRY INTO CORRECTIONS}

\section{A. Judicial and Legislative Assistance}

Women gained entrance into corrections with substantial assistance from Title VII. Throughout the 1960s and 1970s, Congress and the Supreme Court developed this powerful legal doctrine in order to carve out space for women in professions once exclusively held by men. This statutory protection broadened the scope of employment discrimination to include discrimination against women, and provided recourse for women against employers who engaged in discriminatory behavior. Although Title VII provided avenues for women to secure equal employment rights, the doctrine did not contemplate the many issues women would experience in these male-dominated professions, or the coping mechanisms that women might adopt to assimilate into these masculine cultures.

As the Civil Rights movement gained momentum in the 1960s, Congress began to draft legislation to eradicate the most egregious forms of discrimination based on race or color. Through Title VII of the Civil Rights Act of 1964, Congress specifically addressed discrimination in employment based on race and color, and aimed to make it unlawful for any federal government employer to refuse to hire an individual for a discriminatory reason. Although directed at ending discriminatory hiring practices, drafters of the Civil Rights Act did not

chments/CurrentTrendsDCJailPopulation.pdf. Its workforce was less than $35 \%$ female. WORKFORCE Assoc's, InC., A $21^{\text {st }}$ CENTURY WORKFORCE FOR AMERICA's CORRECTIONAL PROFESSION 48 fig. 17 (The American Correctional Ass'n 2004), available at http://www.aca.org/workforce/pdf/PI_CompleteReport.pdf. Currently, it is approximately $90.6 \%$ African American. DC DEP'T OF CORRECTIONS, DC DEPARTMENT OF CORRECTIONS FACTS AND FIGURES 15 (2013), available at http://doc.dc.gov/sites/default/files/dc/sites/doc/ publication/attachments/DC\%20Department \%20of\%20Corrections \%20Facts \%20n \%20Figures \%20Jan\%202013_Updated.pdf.

50 DC Jail Guards Suspended Over Inmate's Striptease, THE ITEM (Aug. 4, 1995), http://news.google.com/newspapers?id=9qQiAAAAIBAJ\&sjid=660FAAAAIBAJ\&pg=6135\%2 C527498 (quoting then Commissioner Margaret Moore as stating that, "[s]uch conduct is reprehensible and a serious threat to security and the orderly running of a correctional institution and will not be tolerated"); Keith A. Harriston, District Paid \$85,000 to Settle Lawsuit by Corrections Officer; Offer Headed Off Testimony on Sexual Harassment, WASH. PosT, Jan. 13, 1994; Keith A. Harriston, D.C. Agency Accused of Harassment; Suit Says Sexual Demands Are the Rule in Corrections, WASH. POST, Jan. 7, 1994. 
originally include women within the provisions of Title VII. ${ }^{51} \quad$ Representative Howard Smith (D-VA), the bill's leading opponent, introduced an amendment that would include women as protected persons under the statute. ${ }^{52} \quad$ After a long debate, the House passed the amendment by a vote of 168 to $133 .^{53}$ As enacted, Title VII provides that, "[i]t shall be an unlawful employment practice for an employer(1) to fail or refuse to hire or to discharge any individual, or otherwise to discriminate against any individual with respect to his compensation, terms, conditions, or privileges of employment, because of such individual's race, color, religion, sex, or national origin." ${ }^{54}$ The Equal Employment Opportunity Act of $1972^{55}$ expanded the coverage of Title VII to include employees of state and local governments. ${ }^{56}$ Courts have since interpreted Title VII as creating and expanding employment opportunities for women. ${ }^{57}$ Consequently, Title VII has led to a substantial increase in the number of women employed in traditionally male-dominated fields.

51 Sacha E. de Lange, Toward Gender Equality: Affirmative Action, Comparable Worth, and the Women's Movement, 31 N.Y.U. REV. L. \& Soc. CHANGE 315, 322 (2007).

52 David L. Rose, Twenty-Five Years Later: Where do We Stand on Equal Employment Opportunity Law Enforcement?, 42 VAND. L. REV. 1121,1131 (1989). But see E. de Lange, supra note 51, at 318 (theorizing that congressional staffers included women in later versions of the bill as an attempt to derail its passage).

53 Rose, supra note 52, at 1131.

54 Equal Employment Opportunities, 42 U.S.C. $\$ 2000$ e-2(a) (2012) (emphasis added).

55 Pub. L. No. 92-261 (amending 42 U.S.C. § 200e-2000e-17). From 1964 until 1972, Title VII did not protect state and local government correctional officers. Thus, it was legal for state and local governments to create gender specific positions until Congress passed the 1972 amendments.

$56 \quad I d$.

57 Rosenfeld v. S. Pac. Co., 444 F.2d 1219, 1225 (9th Cir. 1971) ("The premise of Title VII, the wisdom of which is not in question here, is that women are now to be on equal footing with men.").

58 John C. Smart \& Corinna A. Ethington, Occupational Sex Segregation and Job Satisfaction of Women, 22 RES. IN HigheR Educ. 202, 203 (1987). See Meritor Sav. Bank v. Vinson, 477 U.S. 57, 75 (1986) (acknowledging that sexual harassment is discrimination under Title VII). While Congress worked legislatively to expand women's employment rights, the judicial branch interpreted the Constitution in ways to end gender-based discrimination in ways that helped women enter male-dominated fields. The Supreme Court first extended the Equal Protection Clause of the Fourteenth Amendment to include gender-based discrimination in Reed v. Reed, a case brought by Justice Ginsburg, then a practicing civil-rights attorney. Reed v. Reed, 404 U.S. 71, 76-77 (1971). Five years after Reed, the Court determined that judges should examine gender-based discrimination cases using an intermediate scrutiny framework, meaning that laws that discriminate based on gender must further an important government interest, and the discriminatory behavior must be substantially related to that interest. Craig v. Boren, 429 U.S. 190, 218 (1976) (Rehnquist, J., dissenting) (coining the term "intermediate level scrutiny" to describe the majority's decision). In a later opinion authored by Justice Ginsburg, the Court stated that "[p]arties who seek to defend gender-based government action must demonstrate an "exceedingly persuasive justification' for that action." United States v. Virginia, 518 U.S. 515, 530 (1996) (71, Thomas, J., recused) (striking down Virginia Military Institute's male only admission policy). 
Although Title VII improved women's chances of obtaining employment in jobs previously reserved for men, women still struggled to gain access to higher-level positions within those institutions. Even employers who were willing to hire women assigned female workers to clerical or administrative positions, and reserved higher paying, technical, substantive, or dangerous positions for male employees. ${ }^{59}$ So whether it was to ensure that men continued to have higher paying jobs or to protect women from dangers in the workplace, the net effect even after the passage of Title VII was that women were still excluded from many positions. And often these positions were the ones that led to higher paying or leadership positions in organizations. Frustrated with this experience, women returned to the courts to demand that employers meet the expectations of full access to employment offered by Title VII. ${ }^{60}$

Female correctional workers entered men's penal institutions in the 1970s, ${ }^{61}$ but despite this success, agencies excluded women from most contact positions, due to fears female officers could be easily manipulated or overpowered by male inmates. ${ }^{2}$ To keep women from obtaining contact positions, correctional facilities implemented height and weight restrictions that effectively disqualified most female applicants. ${ }^{63}$

It is against this backdrop that the Supreme Court decided Dothard v. Rawlinson, ${ }^{64}$ eliminating height and weight requirements for women seeking correctional officer positions. In Dothard, Diane Kim Rawlinson, a young woman who had recently graduated from the University of Alabama, with a degree in correctional psychology, applied for a position in the Alabama Department of Corrections ("Ala-

Although the Equal Protection clause confirmed that it was unconstitutional to discriminate based on race, it was not ultimately effective in combatting gender discrimination in the employment sector. See Brandon Garret, Aggregation and Constitutional Rights, 88 Notre DAME L. REV. 593, 625 (2012) ("requirement that the plaintiff show intent to discriminate may explain why in employment discrimination suits, much of the class action litigation is now brought under Title VII of the Civil Rights Act of 1964 (Title VII), rather than under the Equal Protection Clause using § 1983”).

59 Diane Austin, Women and the Offshore Oil and Gas Industry in Southern Louisiana, in History OF THE OFFSHORE OIL AND GAS INDUSTRY IN SOUTHERN LOUISIANA VOLUME I: PAPERS ON THE EVOLVING OFFSHORE INDUSTRY 181 (2008).

60 See, e.g., Rosenfeld v. S. Pac. Co., 444 F.2d 1219, 1223 (1971) (challenging Southern Pacific's policy of excluding women from certain positions where "the arduous nature of the workrelated activity renders women physically unsuited for the jobs," and questioning the constitutionality of a state statute that regulated the number of hours women could work and restricted the weight they could lift.).

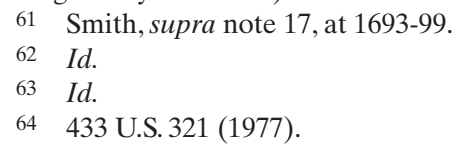


bama DOC"). ${ }^{65}$ The Alabama DOC permitted Rawlinson to work as a counselor, but not as a guard ${ }^{66}$ because her height and weight did not meet the Alabama DOC's requirements for strength. ${ }^{67}$ The Court found that the height and weight restrictions had a discriminatory impact on women, as the standards excluded $41.13 \%$ of the female population but less than $1 \%$ of the male population. ${ }^{68}$ Additionally, the Court found that Alabama DOC's proposed justification for height and weight requirements, the strength required to control inmates, could be tested by other means, and therefore these requirements were prohibited by Title VII. ${ }^{69}$

At the same time that it struck down height and weight restrictions, the Court established that at least for the Alabama Maximum Security Prison at issue in this case, male gender was a BFOQ due to the "jungle-like" conditions within the institution." In an opinion concurring in part and dissenting in part, Justice Marshall disagreed with the majority's reasoning for excluding women from contact positions, stating that " $[\mathrm{t}]$ hough the Court recognizes that possible harm to women guards is an unacceptable reason for disqualifying women, it relies instead on an equally speculative threat to prison discipline supposedly generated by the sexuality of female guards." " Justice Marshall took issue with the majority's reliance on the "employee's very womanhood," and concluded that the majority's "rationale regrettably perpetuates one of the most insidious of the old myths about women that women, wittingly or not, are seductive sexual objects." "72 After Dothard, circuit after circuit took up Marshall's reason-

65 Clare Cushman, Kim Rawlinson: Job Discrimination, in 100 Americans MaKing CONSTITUTIONAL HistORY 167 (Melvin I. Urofsky ed., 2004).

66 Although the Dothard opinion uses the term guard, the preferred term is correctional officer.

67 Dothard, 433 U.S. at 329.

68 Id.

69 Id. at 332. Although Rawlinson asserted violations under both Title VII and Equal Protection, she did plead that the Fourteenth Amendment would require a different analysis. Id. at 334, n.20. The Court, therefore, did not independently discuss the Fourteenth Amendment claim. Id. Rawlinson's co-plaintiff, Brenda Mieth, brought a similar action challenging height and weight requirements for state troopers, using only the Fourteenth Amendment Equal Protection Clause. Meith v. Dothard, 418 F. Supp. 1169, 1182 (M.D. Ala. 1976), aff'd in part, rev'd in part sub nom. Dothard v. Rawlinson, 433 U.S. 321 (1977). The court struck down the height and weight requirements under the Fourteenth Amendment. Id. at 1182. The state chose not to appeal this part of the decision. 433 U.S. at 324, n.4.

70 Dothard, 433 U.S. at 336-37.

71 Id. at 342 (Marshall, J., concurring).

72 Id. at 345. 
ing and granted women access to contact positions in men's penal institutions.

Women experienced similar problems entering other traditionally male-dominated fields, such as the oil industry and the military. ${ }^{74}$ In the oil industry, employers often relegated women to clerical work, rather than allow them equal access to positions in the field as engineers or rig workers. ${ }^{75}$ Similar to women's experience in correctional work, oil companies only admitted women into positions on rigs and platforms after pressure from the civil rights movement. ${ }^{76}$ In contrast, women have always played an integral role in the American military. Until very recently, however, the military did not permit women to serve in combat roles. ${ }^{78}$ In the 1970 s, women's role in the military began to shift to more active roles. ${ }^{79}$ More than forty years later, in Janu-

73 Brenda V. Smith, Watching You, Watching Me, 15 Yale J.L. \& Feminism 225, 270-73 (2003).

74 Although women have made gains in male-dominated employment sectors, they are still underrepresented in many of these fields. By the year 2000, women received more bachelor's degrees than men. More Working Women Than Men Have College Degrees, Census Bureau Reports, U.S. CENSUS Bureau: Newsroom (Apr. 26, 2011), http://www.census.gov/newsroom/releases/archives/education/cb11-72.html. Women, however, are still vastly outnumbered by men in traditionally male-dominated jobs, representing a small percentage of the workforce in "engineering (18\%), physical science, (37\%), mathematical/computer science (34\%), chemistry (26\%), and law (27\%)." Pamela M. Frome et al., Why Don't They Want a Male-Dominated Job? An Investigation of Young Women Who Changed Their Occupational Aspirations, 12 EDUC. RES. \& EVALUATION 359, 360 (2006). Women make up 7\% of the Marine Corps, and 14\% overall of the military's active personnel. Marines Test Women in All-Male Combat Units, ARIZONA DAILY STAR (Dec. 2, 2012), http://azstarnet.com/news/marines-test-women-in-all-male-combat-units/article_88e22d51-b548530c-aadd-b2c0d1f0ecca.html. Tellingly, women represent only $4.5 \%$ of all firefighters, and just $4.3 \%$ of aircraft pilots. Women as a Percent of Total Employed in Selected Occupations, BUREAU OF LABOR STAT. (May 11, 2012), http://www.bls.gov/opub/ted/2012/ted_20120501.htm.

75 Austin, supra note 59, at 181 ("Though women were involved throughout the offshore industry by the mid-1970s, and in smaller companies they worked alongside men in yards and warehouses, they were banned from the highest-paying jobs, those on the rigs and platforms.").

76 Id. ("Following national trends and policies, by the mid-1970s companies were forced to begin employing women in all positions for which they could perform the work.").

77 John Cushman, History of Women in Combat Still Being Written, Slowly, N.Y. TIMES (Feb. 13, 2012), http://www.nytimes.com/2012/02/10/us/history-of-women-in-combat-still-beingwritten-slowly.html ("More than 30,000 women served in World War I, mostly in the nursing corps, and more than 10 times that many in World War II, again mostly in nursing and administration, freeing men for combat.").

78 Id. Press Release, Bureau of Labor Statistics, Americas Youth at 25: School Enrollment, Number of Jobs Held and Labor Market Activity: Results from a Longitudinal Survey (Mar. 22, 2013), available at http://www.bls.gov/news.release/pdf/nlsyth.pdf.

79 Id. ("Along came the first woman to wear two stars, the first to serve as chaplain, the first to fly a helicopter, the first to complete naval flight school, and the first accepted to the service academies."). 
ary of 2013, Secretary of Defense Leon Panetta lifted the ban on women in combat, to a mixed response.

Women working in corrections have seen the most gains in employment opportunities, especially in the past decade. In 2001, women made up just $24.5 \%$ of the correctional workforce in male custodial facilities. $^{81}$ In 2008, women comprised $42 \%$ of juvenile facility staff. ${ }^{82}$ In 2007 female workers made up $40 \%$ of all adult correctional staff, ${ }^{83}$ and were nearing the majority in many correctional work forces. ${ }^{84}$

\section{B. Shortcomings of Legal Assistance}

Despite Title VII's protections and the ensuing gains in women's access to employment, male employees do not necessarily receive female co-workers as equals in the workplace, especially in traditionally male-dominated fields. Women entering male-dominated fields often confront the stereotypes that "women can't manage" or "women will not do whatever it takes to get the job done." cannot mandate acceptance.

80 Kristina Wong, Women Actually on the Front Lines May Not Happen, WASH. TIMES (Feb. 5, 2013), http://www.washingtontimes.com/news/2013/feb/5/symposium-notes-complexitieswomen-combat-issue/.

81 Joann Brown Morton, ACA \& Women Working in Corrections, CORR. TODAY, Oct. 1, 2005 , at 86,87 .

82 BECK, HARRISON, \& GUERINO, supra note 20, at 1.

83 See, e.g., Brooke Hauser, The Changing of the Guard, N.Y. TIMES, Sept. 26, 2008, http://www.nytimes.com/2008/09/28/nyregion/thecity/28guar.html (stating that women represent $45 \%$ of employees in the New York City Department of Corrections).

84 MTC Inst., Women Professionals in Corrections: A Growing Asset 1 (2008), available at http://mtctrains.com/institute/publications/WomenProfessionalsInCorrectionsAug08.pdf. At the Baltimore City Detention Center, female officers comprised more than 60\% of the workforce. See Theresa Vargas, Ann E. Marimow \& Annys Shin, Baltimore Jail Case Depicts a Corrupt Culture Driven by Drugs, Money and Sex, WASH. Post. (May 4, 2013), http://www.washingtonpost.com/local/baltimore-jail-case-depicts-a-corrupt-culture-driven-bydrugs-money-and-sex/2013/05/04/d0cde8a6-b33f-11e2-9a98-4be1688d7d84_story.html.

85 Jill Harrison, Woman in Law Enforcement: Subverting Sexual Harassment with Social Bonds, 22 WOMEN \& CRIM. JUST. 226, 228 (2012) ("Women did not enter policing or corrections as equals, and, if hired, they held unequal positions while often having to portray both masculine and feminine traits simultaneously to fit in and to advance in their careers.").

86 Marie-Line Germain et al., Women Employed in Male-Dominated Industries: Lessons Learned From Female Aircraft Pilots, Pilots in Training and Mixed-Gender Flight Instructors, 15 HuM. RES. DEV. INT'L 435, 444 (2012).

87 Kathryn Abrams, Gender Discrimination and the Transformation of Workplace Norms, 42 VAND. L. REV. 1183, 1187 (1989) (noting that once women gained entry into traditionally male-dominated fields, they experienced strained social relationships, difficulty developing mentoring relationships, were treated in a demeaning manner, or became the subjects of lewd comments). 
Male colleagues may not see women as a part of the work culture, and may view female presence as disruptive or distracting. ${ }^{88}$ Men may not trust female colleagues, fearing that they are not adequately suited to dangerous aspects of jobs. ${ }^{89}$ This distrust can lead to sexual harassment or excluding women from the work culture altogether. ${ }^{90}$

Men sometimes respond to their female co-workers with paternalism, as they do not see their women counterparts as true equals. Men may take on female colleagues' tasks, treat their female colleagues less harshly than male colleagues, or appear more tolerant of questions or mistakes. ${ }^{92}$ Though these behaviors may present as accommodating or supportive, they can hinder women's growth. ${ }^{93}$ Male colleagues may eventually take on a role as a protector of their female co-workers, and attempt to shield their female counterparts from dangerous or unseemly tasks. ${ }^{94}$ This is particularly harmful for women working in corrections, as working with male inmates is often the ladder to promotion prospects.

On the opposite end of the spectrum, men may be hostile to women employees. Male-dominated work cultures can be breeding grounds for sexual jokes, innuendos, and insensitive language. Moreover, supervisors in male-dominated cultures may be more tolerant of

88 Harrison, supra note 85, at 229 ("Female officers often experience less colleague support, particularly when they must juggle their careers with family obligations."); Gloria E. Miller, Frontier Masculinity in the Oil Industry: The Experience of Women Engineers, 11 GEND., WORK \& ORG. 47, 51, 67 (2004).

89 Joseph R. Carlson et al., Correctional Officer Burnout and Stress: Does Gender Matter?, 8 PRISON J. 277, 278 (2003) ("Men officers resent the presence of women coworkers in men's prisons because women are perceived as possessing limited physical strength in responding to emergencies and may not be reliable backups in dangerous or physically threatening inmate encounters."). This resentment could lead to ridicule or sexual harassment. Id. ("In addition, it is not uncommon for men officers to question the professionalism of their women counterparts."). $I d$.

90 Germain et al., supra note 86, at 444 ("Misogynistic behaviors are common in maletyped professions. Male firefighters, for instance, are often skeptical about women's competence as firefighters. They tend to distrust women's motivation for becoming firefighters.").

91 Miller, supra note 88, at 50 ("I really think that, because I'm a woman, they give me more leeway, 'I can explain it to her because she's a woman' - which may not be good, but it makes me more comfortable asking questions. If a man asked them, they might think less of him.”).

92 Id.

93 Id. at 49-50 ("a woman may be viewed as a childlike person in need of protection").

94 BRITTON, supra note 3, at 175 (giving one female correctional officer's response to her male officer's statement that he would never assign her to a dangerous position, "I think that's so sweet! I think it's so sexist, but I mean, I appreciate it!").

95 See infra note 168 (noting that women who work only with female inmates tend not be promoted). 
sexual harassment, even when it is directed at a female worker who has not herself engaged in the sexualized culture.

Because these work places elevate male characteristics, such as power or toughness, women often have a difficult time assimilating to the work culture. ${ }^{97}$ The inability to cope in a male-dominated work culture can lead to high drop-out rates for female employees, further depleting the already small pool of female workers. ${ }^{98}$ Courts have responded to these struggles by further expanding Title VII to include sexual harassment as a form of sexual discrimination. ${ }^{99}$ Despite this protection, women still face higher dropout rates in male-dominated fields. $^{100}$

\section{Coping Mechanisms}

Women who experience harassment or have other difficulties fitting into male-dominated workspaces may adopt any number of characteristics in an attempt to curry favor with male co-workers. Some women develop a nurturing personality; others gravitate towards masculine characteristics, while a few strive to set themselves apart from other women.

Some women find acceptance in a male-dominated field by cultivating a feminine, nurturing personality. ${ }^{101}$ In one study, researchers found that female law enforcement officers were able to mitigate the effects of sexual harassment by creating strong social bonds with their male counterparts. ${ }^{102}$ According to Hirschi's Social Control Theory, the social bonds of commitment, belief, attachment, and involvement "shield officers from deviant and illegal behavior," therefore female

96 Harrison, supra note 85, at 227 ("Work settings that have a higher ratio of men to women and that are considered predominantly male occupations led by a male supervisor may have higher tolerance for sexual harassment.").

97 Id. ("Within these settings, coworker support is more about supporting a male network than it is promoting a place of equal employment opportunity ... [e]xamples of such work environments include the military, law enforcement, firefighting, and construction, in which such traditional characteristics as power, toughness, dominance, aggressiveness, and competitiveness are bonding elements that reinforce group cohesion, often at the expense of females or other minority groups.”).

98 Frome et al., supra note 74, at 360 ("Not only are females less likely to choose careers in those fields, but when they do, they are more likely than males to "drop out' of these fields.").

99 Meritor Sav. Bank v. Vinson, 477 U.S. 57, 75-76 (1986) (acknowledging that sexual harassment is discrimination under Title VII).

100 Frome et al., supra note 74, at 360.

101 Austin, supra note 59, at 173.

102 Harrison, supra note 85, at 226. 
corrections officers can improve relationships with fellow officers by cultivating attachment and involvement with their co-workers."

Some women camouflage themselves by adopting more "masculine" behaviors. For example, women dealt with the male-dominated "wild-west" of the oil industry by assimilating into the masculine culture. $^{104}$ In order to downplay their femininity, women oil workers refrained from wearing feminine clothing or displaying traditionally feminine characteristics, such as empathy. ${ }^{105}$ Many women did not last long in the industry. ${ }^{106}$ Similarly, female workers in law enforcement engaged in the sexual commentary commonplace in male-dominated workplaces in order to gain respect from male colleagues. ${ }^{107}$ Female construction workers faced similar issues, and found that they could not be too sensitive, with one veteran employee remarking, "[i]f you can't handle it, get out. It is their field."

Finally, some women set themselves apart from their female coworkers, in an attempt to gain respect from male colleagues. These so called "queen bees," aim to "emphasize their masculine characteristics (e.g., dominance, independence) and ... stress[] that they were different from other women," in the male dominated workforce.

103 Id. at 229. Most officers already have belief and involvement in their work and thus, levels of social control are best ascertained through commitment and attachment. Attachment is defined as the psychological and emotional connection to others, while commitment is investment in conventional institutions. Id. at 230. The study found that corrections officers have a significantly lower score in the social control scale than police officers. The analysis also found that the prevalence of sexual harassment in the workplace decreased satisfaction; however, social bonds theory can repair some of this damage with 1) attachment to fellow officers, and 2) commitment to the department. This study also found that sexual harassment could affect both male and female officers. $I d$. at 234.

104 Miller, supra note 88, at 66-67.

105 Id.

106 Id. at 68 .

107 Harrison, supra note 85, at 228 ("It can be argued that sexual comments and innuendos exchanged between male and female officers can work to promote some social cohesion and camaraderie rather than unlawful behavior: Some female officers do acknowledge that it can go both ways ... females may not even be aware that they experience discrimination and may simply accept that this type of communication comes with the territory.") (internal citations omitted).

108 Bryna Godar, Female Construction Workers Prove Themselves in a 'Man's Field', MinNESOTA DAILY, June 6, 2012, at 1, 5, available at http://www.mndaily.com/2012/06/06/femaleconstruction-workers-prove-themselves- $\%$ E2\% $80 \% 98$ man $\%$ E2\%80\%99s-field $\%$ E2 $\% 80 \% 99$ (Gallatin, a female construction worker for 12 years, explained that woman need to know what they are getting into and if they believe joking and teasing is harassment, they should not get into construction).

109 Belle Derks, et al., Gender-Bias Primes Elicit Queen-Bee Responses Among Senior Policewomen, 22 PSYCHOL. SCI. 1243, 1243 (2011). 


\section{THREE IMPORTANT LEGAL THEORIES AND THE IMPACT OF FEMALE WORKERS IN CORRECTIONAL SPACES-THE REMIX}

\section{A. Privacy Doctrine and Correctional Spaces}

The Fourth Amendment guarantees "the right of the people to be secure in their persons ... against unreasonable searches. ${ }^{110}$ Although the Fourth Amendment secures the right to privacy from government intrusion for the ordinary citizen, within correctional institutions, inmates retain a very limited Fourth Amendment privacy right. In $\mathrm{Hud}$ son v. Palmer, ${ }^{111}$ the Supreme Court stated:

The recognition of privacy rights for prisoners in their individual cells simply cannot be reconciled with the concept of incarceration and the needs and objectives of penal institutions . . . [a] right of privacy in traditional Fourth Amendment terms is fundamentally incompatible with the close and continual surveillance of inmates and their cells required to ensure institutional security and internal order. ${ }^{112}$

Due to threats of weapons, drugs, and other contraband that could compromise facility security, prisons have great discretion in how and when to search and surveil inmates' cells, property, and bodies. ${ }^{113}$ Body searches, however, are unlike cell or property searches in that " $[\mathrm{m}]$ ost people ... have a special sense of privacy in their genitals, and involuntary exposure of them in the presence of people of the other sex may be especially demeaning and humiliating." ${ }^{114}$ Despite this heightened sense of privacy in one's body, courts have unanimously upheld prison regulations that permit even the most invasive same-sex body searches, in the interest of correctional facility security. ${ }^{11.5}$

In Turner v. Safley, ${ }^{116}$ the Supreme Court established a deferential standard for prisoners' constitutional challenges to prison procedures that infringe upon inmates' rights, such as the right to privacy. The court held that the government needs only a reasonable basis for the regulation, and the infringement on the prisoner's rights must be "reasonably related to legitimate penological interests." 117 In determining reasonableness, courts must examine four factors: (1) whether the le-

110 U.S. CONST. amend. IV.

468 U.S. 517 (1984)

112 Id. at 526-28.

113 John Dwight Ingram, Prison Guards and Inmates of Opposite Genders: Equal Employment Opportunity Versus Right of Privacy, 7 DuKE J. GENDER L \& POL'Y 3, 4 (2000).

114 Lee v. Downs, 641 F.2d 1117, 1119 (4th Cir. 1981).

115 See Bell v. Wolfish, 441 U.S. 520 (1979).

116482 U.S. 78 (1987).

117 Id. at 89. 
gitimate government interest is rationally connected to the prison regulation; (2) whether any alternative means to exercise the right in question exists; (3) whether correctional officers and other inmates will be greatly impacted by an accommodation of the inmate's request; and (4) whether the correctional facility has an alternative means of addressing the issue. ${ }^{118}$ Correctional staff, therefore, have great discretion in conducting even the most intrusive searches of prisoners' bodies, provided those searches are in furtherance of legitimate penological interests. ${ }^{119}$

There are a number of searches that occur in correctional settings, ranging from visual searches of inmates who are clothed or nude that do not involve physical contact, to pat-searches (which involve searches of inmates clothed bodies by "patting" them down), to stripsearches (an increasingly more intrusive search involving the removal of clothing), to body-cavity searches (the most intrusive search that includes inspection of body cavities, including the mouth and genitals). Cross-gender searches and surveillance, those involving staff and inmates of different genders, complicate the privacy doctrine. In contrast to the routine acceptance of same-sex strip-searches, with regard to cross-gender searches, courts have held that "[w]hen not reasonably necessary, that sort of degradation is not to be visited upon those confined in our prisons." ${ }^{120}$ While recognizing the conflicting interests inherent in cross-gender searches and surveillance, courts have found that "[p]rison inmates retain certain rights of privacy under the Fourth Amendment, including the right not to be viewed naked by member of the opposite sex, but that right of privacy is not unlimited." ${ }^{121}$

Even though courts have repeatedly referenced heightened privacy interests with regard to cross-gender searches, courts are most likely to recognize these rights for female inmates. ${ }^{122}$ Courts have consistently protected a female inmate's privacy interests from intrusion by male officers along the continuum of searches. ${ }^{123}$ To the contrary,

118 Id. at 89-90.

119 See Florence v. Bd. of Chosen Freeholders of the Cnty. of Burlington, 132 S. Ct. 1510 (2012) (holding that even detainees arrested and held on misdemeanor charges can be stripsearched).

120 Lee v. Downs, 641 F.2d 1117, 1119 (4th Cir. 1981).

121 Johnson v. Pa. Bureau of Corr., 661 F. Supp. 425, 430 (W.D. Pa. 1987).

122 See Jordan v. Gardner, 986 F.2d 1521 (9th Cir. 1993); Colman v. Vasquez, 142 F. Supp. 2d 226 (D. Conn. 2001). But see Rice v. King Cnty., 243 F.3d 549 (9th Cir. 2000). Male inmate complained that female officer conducted a pat down search, during which she shoved her hand into his testicles. $I d$. at *3. The male inmate claimed he was sexually abused as a child, and he vomited after the search. Id. The court dismissed his Eighth Amendment claim, as he had not produced evidence that the officer knew or had reason to know of his vulnerability. $I d$.

123 Colman, 142 F. Supp. 2d 226 (denying male officer's motion to dismiss female inmate's Fourth Amendment claim challenging a cross-gender search). 
courts have traditionally been less willing to protect a male inmate's privacy rights from female officers. In general, female staff have tremendous latitude to view or touch male inmates. ${ }^{124}$ In some limited instances, courts will protect male inmates' privacy; generally, where female staff engage in prolonged touching or viewing of male inmates' genitals.

For example, in Canedy v. Boardman, ${ }^{125}$ a male inmate alleged that two female correctional officers strip-searched him, although ten male corrections officers were nearby and available to conduct the search. ${ }^{12}$ The court reinstated the inmate's claim, holding that the inmate was "entitled to reasonable accommodation to prevent unnecessary observations of his naked body by female guards." ${ }^{127}$ In practice, female staff may only conduct strip-searches or body-cavity searches of male inmates in exigent circumstances, may perform clothed body patsearches of male inmates, but can only view men while they shower, toilet, or undress, if the viewing is of short duration and inadvertent. ${ }^{12}$ Most recently, in Byrd v. Maricopa County, ${ }^{129}$ the Ninth Circuit held that a county jail could be held liable for a cross-gender pat-search of a male inmate where the inmate was nearly unclothed, the female cadet touched the inmate's penis and scrotum, and the search was videotaped by other cadets who watched. ${ }^{130}$

In limited circumstances, inmates who object to cross-gender searches based on religious reasons are successful in bringing privacy

124 Rebecca Jurado, The Essence of Her Womanhood: Defining the Privacy Rights of Women Prisoners and the Employment Rights of Women Guards, 7 AM. U. J. GENDER SOC. POL'Y \& L. 1, 39 (1999) ("When male prisoners have asserted their right to bodily privacy, the rights of the male prisoners have lost to the employment rights of female guards. While the federal courts have recognized a limited bodily privacy right, they have held that the prisoner's interest in protecting bodily privacy is not as strong as the state's interest in equal employment opportunities for female correctional officers.").

12516 F.3d 183 (7th Cir. 1994).

126 Id. at 184 . (claiming that female officers "regularly observe male inmates in a variety of settings typically considered private, including while they dress, shower, defecate and sleep in various states of undress").

127 Id. at 183.

128 Prison Rape Elimination Act National Standards, 28 C.F.R. $\$ 115.15$ (2012); see Kuntz v. Wilson, 33 F.3d 59 (9th Cir. 1994) (dismissing a male inmate's claim that a female officer could view him in his boxer shorts because "the assignment of female prison officers to positions requiring only infrequent and casual observation of naked male prisoners does not violate the prisoners' right to privacy"); Timm v. Gunter, 917 F.2d 1093 (8th Cir. 1990) (holding prison policy allowing cross-gender pat searches of male inmates was reasonable because there was a penological justification for the policy, and the facility provided training to the officers); Jones v. Harrison, 864 F. Supp. 166 (D. Kan. 1994) (finding that a strip-search conducted by a female officer did not violate male inmate's right to privacy because emergency circumstances justified the search).

129629 F.3d 1135 (9th Cir. 2011).

130 Id. at 1147. 
claims against correctional facilities. ${ }^{131}$ In Jamal v. Smith, ${ }^{132}$ a female officer pat-searched a male plaintiff who was an orthodox Muslim, and not permitted to have physical contact with the opposite sex, even though male officers were present. ${ }^{133}$ The court found that the warden and the individual officer violated the inmate's First Amendment right to freely express his religion, as the search was not reasonably related to a legitimate penological interest. ${ }^{134}$ Other than this limited exception, courts routinely uphold cross-gender pat of male inmates, and show extreme deference to correctional agencies' interests in expanding female correctional staff's employment opportunities. ${ }^{13 .}$

These court decisions assume that "bodily privacy of male prisoners is of little import to the man, i.e., that being viewed or touched by women is not disturbing or harmful to men." ${ }^{136}$ Courts do not perceive male inmates as vulnerable. ${ }^{137}$ Furthermore, courts have elevated women's employment rights over male inmates' privacy rights because those rights were a major impediment to women's entry into correctional spaces. ${ }^{138}$ Courts have either ignored or left unexplored male inmates' actual vulnerability because of the perception that male staff and male inmates are hostile or sexually dangerous, ${ }^{139}$ while female

131 Forde v. Baird, 720 F. Supp. 2d 170 (D. Conn. 2010) (allowing Muslim female inmate's RFRA claim challenging prison policy of non-emergency pat searches by male officers to survive a motion for summary judgment because the prison's interest in staffing were not sufficiently compelling to justify the burden on the inmate's right of free exercise of religion). But see Johnson v. Pa. Bureau of Corr., 661 F. Supp. 425 (W.D. Pa. 1987) (rejecting a Muslim inmate's First Amendment claim because his claim regarding his religious belief was not sincere).

132 No. 09-1421, 2010 WL 375160, at *1 (C.D. Ill. Jan. 22, 2010).

133 Id. at $* 1$.

$134 I d$. at $* 2$.

135 Letcher v. Turner, 968 F.2d 508 (5th Cir. 1992).

136 Jurado, supra note 124 , at 39.

137 Russell K. Robinson, Masculinity as Prison: Sexual Identity, Race, and Incarceration, 99 CALIF. L. REV. 1309, 1314 (2011) ("The Jail, reflecting the broader society's gender stereotypes, requires heterosexual men to assume traditionally masculine traits, including physical aggression, a commitment to denying one's vulnerability, and a refusal to turn to government for protection”); see also Griffin v. Mich. Dep’t of Corr., 654 F. Supp. 690 (E.D. Mich. 1982) (finding the invasion of privacy for male inmates viewed by female officers, "no more than if a woman doctor examines them").

138 See also Jurado, supra note 124, at 28-29 ("Taking the lead from the court in Gunther, several district courts and circuit courts tipped the balance of rights in favor of the employment opportunities of female guards as against a correctional administrator's asserted concern for the privacy rights of male prisoners.").

139 See, e.g., Oliver v. Scott, 276 F.3d. 736 (5th Cir. 2002) (upholding the district court's denial of inmate's equal protection claim based on the dangerousness of male inmates, and also noting that male inmates were not similarly situated to the female inmates because the facility had six times as many men as women, male transfer inmates had been convicted of violent crimes while female inmates had been convicted of low-level felonies, and male units were more prone to sexual predation). 
correctional officers are seen as professional and asexual. ${ }^{140}$ These expectations of normative behavior do not necessarily conform to reality, yet courts have developed privacy doctrine based on these gender stereotypes rather than fact.

The price of women's entry into correctional spaces has not only been the loss of dignity and privacy of male inmates, but also the same losses for female inmates. Additionally, while cases suggest that an additional price for female inmates has been sexual abuse, more recent data also supports that men and boys in custody have experienced sexual abuse at the hands of female staff. ${ }^{141}$ When women first gained entry into male correctional facilities, they often abandoned working in women's facilities, where the staff had been historically female. Hewing to the purposes of Title VII to provide equal employment opportunities based on an individual's ability to perform the job rather than her gender, men reentered women's facilities making the argument if women could supervise men then they should be able to supervise women. ${ }^{142}$ Almost immediately, female inmate claims of sexual abuse and trauma related to searches by male officers confronted judges. ${ }^{143}$ In the earliest cases, judges sought modifications like privacy panels, knock and announce, and clothing for female inmates while they slept. ${ }^{144}$ These modest changes, however, were not enough in courts' view to protect female inmates, and courts began to use the BFOQ doctrine to carve out safer spaces for female inmates.

\section{B. Shortcomings of Title VII and How the BFOQ Doctrine Fails to Adequately Address Gendered Employment Decisions}

Like any first generation remedy, Title VII was a blunt instrument. Rather than creating nuanced employment opportunities, Title VII established an absolute prohibition on discriminatory practices in

140 See Johnson v. Phelan, 69 F.3d 144, 147 (7th Cir. 1995) (stating that using female officers was a good use of staff); Grummett v. Rushen, 779 F.2d 491, 496 (9th Cir. 1985) (noting the professionalism of female corrections officers). But see Wood v. Beauclair, 692 F.3d 1041, 1044-45 (9th Cir. 2012) (detailing the sexual aggressiveness of a particular female officer).

141 See supra Section III.

142 See, e.g., Breiner v. Nev. Dep't of Corr., 610 F.3d 1202 (9th Cir. 2010) (holding that female sex was not a bona fide occupational qualification).

143 See, e.g., Jordan v. Gardner, 986 F.2d 1521 (9th Cir. 1993) (challenging the Washington Corrections Center for Women's policy that permitted male correctional officers to conduct random pat-down searches of female inmates).

144 See, e.g., Forts v. Ward, 621 F.2d 1210 (2d Cir. 1980) (assuming, without deciding, that female inmates had a privacy right that prevented male correctional officer from viewing female inmates while they were sleeping, changing clothes, or using the toilet and requiring the facility to permit inmates to cover their cell windows for fifteen minute intervals). 
employment based on sex. ${ }^{145}$ As a result, some hiring practices that were not intended as discriminatory, but were instead based on legitimate business concerns, became unlawful. ${ }^{146}$ The drafters of Title VII included an escape clause; the BFOQ that permits employers to discriminate in employment in very narrow circumstances. The BFOQ exception specifically permits an otherwise discriminatory hiring practice when it is "reasonably necessary to the normal operation of that particular business or enterprise." ${ }^{147}$ Plaintiffs typically invoke the BFOQ doctrine in gender-based discrimination cases. ${ }^{148}$

To succeed on a BFOQ defense, the defendant must show that: 1) the job qualifications offered to justify the BFOQ relates to the essence or central function of the facility; and 2) they must be "reasonably necessary" to the facility's business. ${ }^{149}$ Courts have indicated that the BFOQ defense is an "extremely narrow exception" to the general prohibition of discrimination on the basis of sex.

In 1980, in Gunther v. Iowa State Men's Reformatory, the Eighth Circuit recognized that correctional facilities may be able to create BFOQs when a position required "shower and toilet surveillance, strip search and related duties ... for males at [the male prison], or females at the women's institution." ${ }^{151}$ Over the next thirty years, the BFOQ doctrine developed along mostly gendered lines, and correctional authorities most often use the doctrine to protect female inmates from harm, in recognition of the vulnerability of women in custody. Correctional facilities have most frequently established female gender as a

145 "It shall be an unlawful employment practice for an employer- (1) to fail or refuse to hire or to discharge any individual, or otherwise to discriminate against any individual with respect to his compensation, terms, conditions, or privileges of employment, because of such individual's race, color, religion, sex, or national origin.” 42 U.S.C. § 2000e-2(a)(1) (2012).

146 Title VII gives plaintiffs two options to challenge employment decisions, disparate treatment or disparate impact. The BFQO defense is available in cases of disparate treatment. See generally, Dothard v. Rawlinson, 433 U.S. 321 (1977) (upholding a BFOQ of male gender). In disparate impact cases, employers can use the business necessity test, and will prevail where they can show that the employment practice in question is predictive of successful job performance. See Griggs v. Duke Power Co., 401 U.S. 424, 432. (1971) (holding that requirements of a high school diploma or successful completion of a standardized test where not indicative of satisfactory of job performance and unfairly impacted African American applicants).

14742 U.S.C. $\$ 2000 \mathrm{e}-2(\mathrm{e})(1)$ (2012).

148 Katie Manley, The BFOQ Defense: Title VII's Concession to Gender Discrimination, 16 DUKE J. GENDER L.\& POL'Y 169, 198-99 (2009) ("The BFOQ defense if rooted in the belief that some very real and unavoidable differences exist between women and men that can cause one gender to be better equipped for a position than the other.").

149 See Western Air Lines, Inc. v. Criswell, 472 U.S. 400, 413-14 (1985).

150 See, e.g., Dothard, 433 U.S. at 334.

151 Gunther v. Iowa State Men's Reformatory, 462 F. Supp. 952, 955-56 (N.D. Iowa 1979), aff'd, 612 F.2d 1079 (8th Cir. 1980). 
BFOQ in order to protect the privacy of female inmates, ${ }^{152}$ using female gender BFOQ to hire exclusively female employees, ${ }^{153}$ or to change the gender of a particular shift.

In Everson v. Michigan Department of Corrections, ${ }^{155}$ the Sixth Circuit upheld a BFOQ of female gender for an all-women's correctional facility operated by the Michigan Department of Corrections ("MDOC"). For years, the facility had been plagued with rumors of sexual assaults. ${ }^{156}$ In response to inmate complaints, Human Rights Watch reported that "rape, sexual assault or abuse, criminal sexual contact, and other misconduct by corrections staff are continuing and serious problems within the women's prisons in Michigan [and] have been tolerated over the years at both the institutional and departmental levels." ${ }^{157}$ Upon recommendations, the MDOC assigned a certain number of positions as "female only," in an attempt to prevent further sexual assaults. $^{158}$ Female and male staff plaintiffs, represented by the correctional officers union, filed suit; alleging that their employment prospects were harmed as a result. ${ }^{159}$ Female correctional officer plaintiffs argued that they would have to do more work, while male correctional officers complained about being denied these positions. $^{160}$ Affording discretion to the MDOC, the court found that the "exclusion of males from these positions is 'reasonably necessary' to 'the normal operation' of the MDOC's female facility" to prevent sexual abuse of female inmates.

Employers may not, however, rely on gendered stereotypes to create BFOQs, and courts will not allow BFOQs solely on the assumption that males may be sexually predatory towards female in-

152 Reed v. Cnty. of Casey, 184 F.3d 597, 598 (6th Cir. 1999) (holding that the jail was permitted to change a deputy jailer's shift from day to overnight to accommodate the need for an onduty female deputy because the plaintiff's female gender was a BFOQ).

153 Torres v. Wis. Dep't of Health and Soc. Servs., 859 F.2d 1523, 1525 (7th Cir. 1988).

154 Robino v. Iranon, 145 F.3d 1109, 1111 (9th Cir. 1998) (finding that female gender was a BFOQ for six correctional-officer first watch positions necessary to control sexual conduct and accommodate privacy interests of female inmates).

155 Everson v. Mich. Dep’t of Corr., 391 F.3d 737 (6th Cir. 2004) (finding that female gender was a BFOQ for correctional officer positions in the female housing facilities).

156 Id. at 741 (stating that to Michigan Women's Commission "sexual assault and harassment are not isolated incidents and that fear of reporting such incidents is a significant problem").

157 Human Rights Watch All Too Familiar: SeXual Abuse of Women In U.S. State PRISONS 224 (1996).

158 Everson, 391 F.3d at 745-46.

159 Id. at 740.

160 Id. at 740-41.

161 Id. at 753. 
mates. ${ }^{162}$ Although facilities may not rely on gender stereotypes in forming BFOQs, courts do, in fact, uphold more BFOQs for women, perhaps due to the notion that men "cannot stifle their sexual thoughts from surfacing while at work." ${ }^{, 63}$ In contrast, male gender is almost never acceptable as a BFOQ in correctional settings, except when supervision of juvenile inmates is at issue. ${ }^{164}$

Gender stereotypes that agencies often use to justify BFOQs complicate Title VII's gendered response to employment discrimination. ${ }^{165}$ Some scholars argue that courts' reliance on BFOQs in privacy situations may stifle true gender equality, and that challenging gender norms better address the proscriptions of Title VII. ${ }^{166}$ As it stands, Title VII and the BFOQ doctrine have helped women gain access to correctional institutions, but have not managed to take into account individualized vulnerabilities of either female correctional workers or male inmates, or for that matter, female inmates. In this way, these legal doctrines perpetuate stereotypes and sidestep the issue of female-perpetrated abuse in correctional settings. ${ }^{16}$

The aims of Title VII and the BFOQ defense may be complicated by the fact that women who work only with female inmates tend not to be promoted. ${ }^{168}$ Within correctional cultures, there is a pecking order derived from on-the-job experience. ${ }^{169}$ Those with expertise and experience gained while working with high custody level inmates

162 Breiner v. Nev. Dep’t of Corr., 610 F.3d 1202, 1216 (9th Cir. 2010) (ruling that gender was not a BFOQ for correctional staff positions at an all-women's facility because the Nevada Department of Corrections could not conclusively prove that hiring men would subject inmates to sexual abuse, or subject employees to tolerating sexual abuse by their subordinates).

163 Manley, supra note 148, at 190 ("Men are often stereotyped as sexually motivated, having 'one-track minds' that cannot stop them from ogling the naked female body. Whatever the reason, these stereotypes result in a discriminatory double standard in hiring and staffing procedures. Serious concerns arise when privacy BFOQs are actually premised upon stereotypes, however, since this contradicts the express rejection of stereotypes as valid BFOQ motives.").

164 Id. at 178; see, e.g., In re Juvenile Det. Officer Union Cnty., 837 A.2d 1101 (N.J. Super. Ct. App. Div. 2003) (permitting a BFOQ for positions supervising juveniles).

165 Suzanne Wilhelm, Perpetuating Stereotypical Views of Women: The Bona Fide Occupational Qualification Defense in Gender Discrimination under Title VII, 28 WOMEN's RTS. L. REP. 73, 91 (2007) (noting that courts "foster[] the view that women are weak and must be protected, and/or they are seductive sexual objects and must be kept separate from men").

166 Sharon M. McGowan, The Bona Fide Body: Title VII's Last Bastion of Intentional Sex Discrimination, 12 COLUM. J. GENDER \& L. 77, 127(2003) (arguing that although BFOQ positions may prevent some types of sexual abuse of inmates, reliance on the BFOQ does not promote the equality Title VII envisioned).

167 Manley, supra note 148, at 206 ("The most significant problem with the BFOQ defense occurs because of the validating effect it has on current gender stereotypes. Permitting sexual stereotypes reinforces them, allowing them to carry on far into the future. What's more, legal reinforcement sends a much stronger message than social reinforcement.").

168 Interview with Kathy Dennehey, Former Comm'r, Massachusetts Dep't of Corr., (Feb. 1, 2013).

169 Id. 
(most women are held at lower custody levels), tend to get promoted. When men or women do not apply to work at female sites for fear of career stagnation, women employees are often forced to remain on shift work because they must perform same-sex searches. ${ }^{17}$ This situation creates tension between women who work with female inmates and women and men who work with male inmates. ${ }^{172}$ A better response to the equality and opportunity conundrum may lie in recognizing that certain people are more vulnerable than others regardless of gender, and making proper arrangements for them. ${ }^{173}$ In addition, agencies could accomplish the aims the BFOQ exception was designed to address by simpler measures, such as rearranging work assignments, or ensuring that measures other than working at a particular facility correlate with requirements for more advanced positions. ${ }^{174}$ Indeed with the advent of technology, women's employment and exposure to training in non-traditional professions like the military, and women's mastery of many physical tasks at the same or equivalent level as men, the old proxies for advancement, such as strength, endurance, or work in maximum-security prisons, are no longer proxies for promotion to higher-level positions. ${ }^{175}$ Moreover, providing accommodations for inmates' gender preference in supervision may be important to therapeutic goals of providing role models, because inmates may be more comfortable and willing to discuss intimate, gender-specific topics with physicians and counselors of the same gender, and shared physicality.

\section{Vulnerability as the Measure of Protection}

Title VII is problematic in the way that it fails to account for multiple vulnerabilities. This legal doctrine has created protected classes that are both over and under-inclusive, and only offers protection for

170 Id.

171 Id.

172 Id.

173 See infra Section IV.

174 Interview with Kathy Dennehey, Former Comm'r, Massachusetts Dep’t of Corr. (Feb. 1, 2013).

175 See infra Section III.

176 Emily Gold Waldman, The Case of the Male Ob-Gyn: A Proposal for the Expansion of the Privacy BFOQ in the Healthcare Context, 6 U. PA. J. LAB. \& EMP. L. 357, 388 (2004) ("[T]hat preferences for same-gender healthcare that relate to physical modesty should not be given more deference than preferences relating to therapeutic interests, and, moreover, that neither type of preference should be dismissed as simply masking malignant, stereotypical attitudes about appropriate gender roles. Both types of preferences clearly relate directly to the essence of many healthcare businesses, and neither relies on nor perpetuates a chauvinistic conception of the genders."). 
discrimination based on certain characteristics, such as race or sex. ${ }^{177}$ Assigning or excluding an individual from a protected class, and thus granting or denying protection from discrimination, overlooks other variables that affect an individual's vulnerabilities, such as class or socioeconomic status. Individuals typically included within protected groups may be more or less vulnerable than other group members due to societal and institutional factors, and would therefore possibly require degrees of protection unique from fellow class members. For example, the first women to enter corrections were white women. Although their gender created vulnerability, they were often protected by their race and class. Today, race and class still operate to provide greater protection to individuals performing the same job. Other factors, such as marital status, may also act to confer greater power or less vulnerability. While Title VII offers access and opportunity to members of protected classes, it fails to factor in the varying vulnerabilities of class members that can become exacerbated once an individual has entered into a previously inaccessible and this inhospitable space.

Martha Fineman critiques the Equal Protection doctrine, and posits that society has interpreted equality to require sameness of treatment; that in order to achieve equality, one must be treated as an equal, despite one's particular circumstances or abilities. ${ }^{178}$ For Fineman, the focus on sameness of treatment ignores real differences that exist between men and women, and between individuals of the same gender, and ultimately stifles the discourse about equality. Fineman rejects the "identity approach to equality," which only extends protection from discrimination to individuals who bear characteristics common to a member of a protected class, as defined under the Equal Protection doctrine.

According to Fineman, the identity approach fails due to its insistence that all individuals have access to, and the capacity to achieve, equality. ${ }^{180}$ Instead, Fineman recommends imbedding the equality discourse within the concept of vulnerability, "the characteristic that positions us in relation to each other as human beings." ${ }^{181}$ Vulnerability is both universal and constant. Everyone is vulnerable to an "ever present possibility of harm, injury, and misfortune," much of it occurring

177 See generally Martha Albertson Fineman, The Vulnerable Subject: Anchoring Equality in the Human Condition, 20 YALE J.L. \& FEMINISM 1 (2008).

178 Martha Albertson Fineman, The Vulnerable Subject and the Responsive State, 60 EMORY L.J. 251, 251 (2010).

179 Id.

180 Id. at 254.

181 Id. at 255. 
outside of one's control. ${ }^{182}$ This universal and constant harm, however, does not have an identical impact on all people. ${ }^{183}$ Although vulnerability can be universal, the specific impact of vulnerability on an individual is variable depending on the "quality or quantity of resources we possess or can command."

Another feminist theorist, Janet Halley, recommends stepping back from gendered responses to discrimination entirely. Halley advises that one cannot always assume gender-conforming behavior. ${ }^{18}$ Advancing employment for women within male-dominated spaces through the use of Title VII or another legal doctrine may lead to unexpected results, without understanding that women will not always behave according to gender norms.

Taking Fineman and Halley's critiques together, it seems that Title VII is an uncomfortable fit for the situations that female correctional workers face. So, do we continue to squeeze female correctional workers, or all women and men for that matter, into the narrow confines of Title VII, or do we expand the space in which women and men, to the extent those monikers continue to be appropriate, operate? ${ }^{186}$ Yes, let's expand them, but how? How does one start and how does one carefully chart a path that keeps the best of existing law, but pushes for a greater recognition of our shared and multiple vulnerabilities?

A good beginning would be to acknowledge the vulnerabilities of protected class members and to account for them, rather than shoehorning all members into the same pattern. ${ }^{187}$ In the case of female correctional workers, there is important empirical work needed to document the changing demographics of this group. They are an important group to map because they are at the epicenter of important and overlapping narratives of power, vulnerability and sexuality. First,

182 Id. at 267.

183 Id. at 268 ("Negative economic and institutional harms may cluster around members of a socially or culturally determined grouping who share certain societal positions or have suffered discrimination based on constructed categories used to differentiate classes of persons, such as race, gender, ethnicity, or religious affiliation.").

$184 I d$. at 69.

185 See Janet Halley, Split Decisions: How And Why To Take A Break From FEMINISM (2006).

186 Cf. Richard Pérez-Peña, College Health Plans Respond as Transgender Students Gain Visibility, N.Y.TIMES, Feb. 12, 2013, at A16.

187 Kathryn Abrams, Gender Discrimination and the Transformation of Workplace Norms, 42 VAND. L. REV. 1183, 1191-92 (1989) (suggesting that women entering male-dominated professions are disadvantaged by the fact the workplace has been constructed by male norms, that do not fully appreciate the unique experiences and perceptions of women, stating the women should "challenge the pervasive influence of male-generated norms through introduction of women's perspectives). 
they are a part of the burgeoning punitive state. ${ }^{188}$ Given the widening income disparities in this country in particular, methods of holding on to what one has and punishing those who threaten that security are growth industries. ${ }^{189}$ Women are seen as perfect for these positions because they are not a threat. At the same time, they legitimatize these systems of control by serving as the poster children for achievement, e.g. "if women can make it anyone can."

Yet, female correctional officers have multiple vulnerabilities. First, while they are a growing population in the correctional workforce, they are still underrepresented in leadership positions, which are still male-dominated. ${ }^{190}$ Second, they are overwhelmingly single women; regardless of what one thinks about the institution of marriage, it carries powerful privileges - economic, social and physical. ${ }^{191}$ Married couples earn more than single women. The economic system in the U.S. favors marriage with tax and other benefits. The social approbation that accompanies marriage also carries many benefits. Also, married people are healthier and live longer. ${ }^{193}$ Third, women in corrections are often single parents, and there are multiple vulnerabilities associated with that status. Finally, they are often women of color, another vector of vulnerability that overlaps with the identity of the correctional population in the United States, which is disproportionately male, black, Latino, and poor.

Because of the demographics of women in corrections and people under correctional supervision - there is often consanguinity and identity. Female correctional workers are often related to, and from

188 See Michelle AleXander, The New Jim Crow: Mass InCARCERATiOn In the Age OF COLORBLINDNESS (2010).

189 See, e.g., Louis Woodhill, The Mystery of Income Inequality Broken Down into One Simple Chart, FORBES (Mar. 28, 2013), http://www.forbes.com/sites/louiswoodhill/2013/03/28/themystery-of-income-inequality-broken-down-to-one-simple-chart/; Tio Hardiman, The Prison Industrial Complex in the United States, HufFINGTON PosT (Oct. 18, 2011, 1:57 PM), http://www.huffingtonpost.com/tio-hardiman/the-prison-industrial-com_1_b_994221.html.

190 MTC Inst., Women Professionals in CORRECTIONS: A GRowing Asset 23 (2008) (noting that the percentage of women in authority positions in correctional institutions has grown, but is still small relative to the number of men in authority positions).

191 Ralph Richard Banks, Is Marriage for White People? How the African AMERICAN MARriage DECLINE AFFeCts EVERYONE 60-61 (2011).

192 Lisa Arnold \& Christina Campbell, The High Price of Being Single in America, THE ATLANTIC (Jan. 14, 2013), http://m.theatlantic.com/sexes/archive/2013/01/the-high-price-ofbeing-single-in-america/267043/.

193 Id.

194 James Forman, Jr., The Black Poor, Black Elites, and America's Prisons, 32 CARDozo L. REV. 791, 798 (2011) (finding forty percent of corrections officers are woman of color); see also ALEXANDER, supra note 188, at 138. 
the same background, as the individuals they supervise. ${ }^{195}$ Often, lowincome women become security personnel supervising people - youth, other women, and men - drawn from their community by systems of control. $^{196}$ For example, in some neighborhoods in Washington, DC, there are six men for every ten women:

With so many men locked up, the ones left think they can do whatever they want .... A man will have three mistresses, and they'll each put up with it because there are no other men around .... Epidemiologists have found that when the incarceration rate rises in a county, there tends to be a subsequent increase in the rates of sexually transmitted diseases and teenage pregnancy, possibly because women have less power to require their partners to practice protected sex or remain monogamous.

These demographics may begin to explain the involvement of female correctional workers in staff sexual misconduct disproportionate to their numbers in the correctional workforce. Freedom of association or fraternization is very limited in custodial and security settings. ${ }^{198}$ In fact, most agencies have policies that prohibit staff from personal interaction with inmates or their family. ${ }^{199}$ Yet, the pool of likely partners for female correctional workers, by virtue of their gender, race, and class, is very limited as well. According to June Carbone and Naomi Cahn, a woman's likelihood of marriage is directly related to her economic status and the scarcity or abundance of likely partners. ${ }^{200}$ Women become highly valued as partners in custodial settings because they are few and have access to valuable resources, e.g. "real" sex in a sex segregated environment, food, communication with the outside, and the power of their positions. ${ }^{20}$

195 See, e.g., Brooke Hauser, The Changing of the Guard, N.Y. TIMES (Sept. 28, 2008), http://www.nytimes.com/2008/09/28/nyregion/thecity/28guar.html; see also ALEXANDER, supra note 188 , at 138 .

196 See generally Michel Foucault, DisciPline AND PUNISH: THE BIRTH OF THE PRISON (Alan Sheridan trans., Vintage Books 1979) (1975).

197 John Tierney, Prison and the Poverty Trap, N.Y. TIMES (Feb. 18, 2013), http://www.nytimes.com/2013/02/19/science/long-prison-terms-eyed-as-contributing-topoverty.html? pagewanted=3\&_r=0\&emc=eta1.

198 Brenda V. SMith \& Melissa C. Loomis, Project on Addressing Prison Rape, ANTI-FraternizATION POLICES AND THE FiRst AMENDMENT (2013).

199 Id.

200 See NaOmi CAHn \& June CARbone, Red Families V. Blue FAmilies: Legal Polarization And The Creation OF Culture (2010).

201 Marimow \& Wagner, supra note 38 (describing how male inmates used their sexual relationships with female correctional officers to further a drug conspiracy). 
The converse is true in the community where desirable men are scarce and men can pick and choose their partners. ${ }^{202}$ Likewise, in reported narratives of women who became sexually involved with men in custody, they spoke of all of the benefits of partnering that they were denied in relationships outside of custodial settings and that they had access to inside. ${ }^{203}$ They spoke of being protected from other inmates and staff in a hostile work environment. ${ }^{204}$ They described male inmates' physical and emotional availability. ${ }^{205}$ They also described feeling in control of the relationship, even if that control was illusory given the hostile work environment, the risk of discovery, and the potential administrative and criminal sanctions. ${ }^{206}$

\section{Minding the GaP - What is a Good Feminist to Do?}

I recently discussed the problem of female correctional workers sexual interactions with men and boys in custody in Uncomfortable Places, Close Spaces. ${ }^{207}$ In that article, I made several policy prescriptions, some of which continue to be salient here. First, and foremost, I acknowledge and account for the multiple vulnerabilities of all of the parties. Some of those vulnerabilities receive constitutional protection, while others do not. For female correctional workers, they receive the protections of the Equal Protection Clause and Title VII at a minimum. Individuals in custody likewise receive constitutional protection under the Fourth, Fifth, Eighth, and Fourteenth Amendments.

Second, correctional authorities must address the sexualized culture and hostile environment that exists in many agencies. This sexualized culture is manifest in sex and corruption scandals such as the ones in Maryland ${ }^{208}$ and New York ${ }^{209}$ and in female staff's claims of hos-

202 Dorothy E. Roberts, The Social and Moral Cost of Mass Incarceration in African American Communities, 56 STAN. L. REv. 1271, 1272-73 (2004) ("African Americans experience a uniquely astronomical rate of imprisonment, and the social effects of imprisonment are concentrated in their communities.").

203 Focus Groups, Regional Training Responding to Sexual Abuse of Inmates in Custody: Addressing the Needs of Men, Women and Gender Non-Conforming Populations, in Milwaukee, Wisc. (Mar. 2013).

204 Id.

205 Id.

206 Id.

207 The paper was part of a symposium on women in custody. I chose to present on and write about female correctional workers. Brenda V. Smith, Uncomfortable Places, Close Spaces: Female Correctional Workers' Sexual Interactions with Men and Boys in Custody, 59 UCLA L. REV. 169 (2012).

208 Ian Duncan \& Jessica Anderson, Federal Authorities Indict Alleged Gang Members, Jail Guards, BALT. Sun (Apr. 24, 2013), http://articles.baltimoresun.com/2013-04-24/news/bs-md-cibgf-jail-indictment-20130423_1_jail-guards-city-jail-corrections-officers; Ann E. Marimow \& John Wagner, 13 Corrections Officers Indicted in Md., Accused of Aiding Gang's Drug Scheme, 
tile environment discrimination in California and Florida. ${ }^{210}$ This culture breeds sexual predation and opportunism by both inmates and staff, much of which involves female staff as targets and aggressors. Enforcement of policies and laws prohibiting sexual contact between staff and inmates are an important part of that response, as are enforcement of policies and laws that prohibit sexual harassment, sex discrimination, and demeaning language between staff. These measures have the potential to improve the culture of agencies, break the code of silence related to sexual abuse and opportunism in custo$\mathrm{dy}$, and redound to the benefit of female correctional workers and inmate and youth targets of this behavior.

Third, research indicates that female correctional workers view their work environment as hostile, not only because of the dangerous work conditions, but also because they face discrimination and abuse from inmates, coworkers and superiors. While several professional organizations to support and mentor women working in corrections exist, ${ }^{211}$ much of their work has been on career advancement. Like men, women need access to good models of ethical leadership. Yet, these organizations may be missing an opportunity to articulate a nuanced yet aggressive approach to female staff who engage in sex with men and boys in custody. Termination and prosecution for predatory or opportunistic sexual behavior with individuals under custodial supervision is unquestionably a bar to career advancement with the potential for long term consequences including sex offender registration. $^{212}$

Fourth, researchers and policymakers must understand that female correctional workers are at the epicenters of several major demographic and cultural fault lines -- mass incarceration of poor and minority men, ${ }^{213}$ the diminishing access to marriage for low income women, ${ }^{214}$ and the impact of mass incarceration on female workers, in

WASH. POST (Apr. 23, 2013), http://articles.washingtonpost.com/2013-0423/local/38756337_1_black-guerilla-family-bgf-state-prison.

209 Mosi Secret, Impregnated by Prisoner, Guard Now Faces Charges, N.Y. TIMES (Feb. 5, 2013), http://www.nytimes.com/2013/02/06/nyregion/police-killers-jailer-now-pregnant-with-hischild-is-charged .html.

210 Michael Doyle, Women Workers at Florida Prison Win Class-Action Status in Sexual Harassment Case, MiAmI HERALD (May 29, 2013), http://www.miamiherald.com/ 2013/05/29/3422834/women-workers-at-florida-prison.html.

211 ASSOCIATION OF WOMEN EXECUTIVES IN CORRECTIONS, www.awec.us (last visited July 15, 2013).

212 See e.g., COlo. REv. StAT. AnN. § 16-22-102 (West 2010) (including "engaging in sexual conduct in a correctional institution" within the definition of a registrable offense).

213 ALEXANDER, supra note 188, at 138.

214 CAHN \& CARBONE, supra note 200. 
particular on women of color, and on their opportunities for developing intimate relationships with men outside of work. Female correctional workers are less likely to be married, are more likely to be single parents, and are often double minorities - of color and gender-in their workplaces. Because Title VII has created opportunities for women to work in the male and female facilities, and because they are more likely to be able to meet the employment criteria, female correctional staff find themselves in entry-level jobs supervising men who but for their status could be likely mates. Training for staff, especially female staff, must discuss the demographics of the correctional population and the correctional workforce and the likelihood that correctional staff will meet someone they know or someone toward whom they will develop sexual attraction, or both. With more information of this kind, training could focus on the appropriate response to the attraction and emphasize the importance of maintaining professionalism and avoiding acting on such impulses. Rather than perpetuating the nineteenth century myth of women's lack of sexual interest, best practices in twenty-first century corrections training could address the reality of women's work in correctional environments, and the impact of mass incarceration on their work and social prospects.

Finally, legal scholars need to imbed their theories in reality rather than conjecture and stereotype. We must test our theories with empirical work that draws upon both qualitative and quantitative methods. In the instant case, legal scholars must draw upon or study women's experiences in non-traditional environments and determine how current legal theories assist or hinder their entry and tenure in these settings. These theories must be nimble and durable enough to address the complicated intersections of class, race, gender, and other vulnerabilities for female correctional workers and the individuals, male and female, under their custodial supervision. 